\title{
A Case Study On Swarm Intelligence Based Senor Network Optimization
}

\author{
K.Anitha ${ }^{1}$ \\ Sri Chandrasekharendra Saraswathi Viswa Mahavidyalaya Deemed to be University ${ }^{1}$ \\ Department of Electronics and Communication Engineering ${ }^{1}$ \\ Email:anithaanbu100@gmail.com ${ }^{l}$
}

\begin{abstract}
Wireless senor network technology was the promising technology applied for many applications. The performance of network is highly depends on architecture, routing algorithm and protocols. There has been a rapid growth in Research on swarm intelligence and many of the researcher has been selected swarm intelligence concept for senor network optimization. This research paper is a review of swarm intelligence were applied in the wireless senor network optimization
\end{abstract}

Keywords- Swarm intelligence, Artificial Bee Colony, Wireless Sensor Network

\section{INTRODUCTION}

Wireless sensor network (WSN) widely used in monitoring purpose which is formed by collective of sensor nodes deployed in the monitoring domain.
Sensor node is developed by integrating sensors with processing unit, transceiver, memory unit, and external power supply. Figure.1 is sensor node architecture.

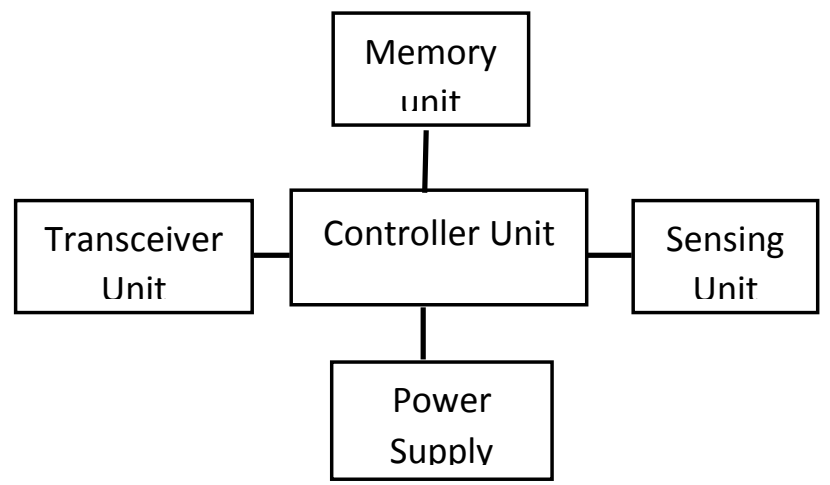

Fig. 1. Sensor Node Architecture

Sensor nodes sense the environment and sends the gathered the information to the sink node in terms of wireless communication and defined as sensor network. The size of the network is depends on the density of the nodes, sink node in a network has been selected single or multiple centered by density of nodes[1]. The network performance is assessed by its architecture topology, routing technique and characteristic like lifetime, responsive, robustness, scalability, heterogeneity, and self-configuration. WSN was widely used in many real time application like Military applications, Environmental applications, Health applications, Home applications and other commercial applications[2]

Researchers has been adopted techniques for sensor network performance optimizations in terms of routing techniques, network topologies, data aggregation and synchronization for providing low cost limited energy constrain and self-organized network. Gaussian distribution, genetic algorithms, Radio Sleep Mode Optimization and Particle Swarm Optimization are some of the optimization models available in WSN[3] .

\section{SWAM INTELLIGENCE}

In the year of 1989 the swarm intelligent concept was introduced by Gerardo Beni and Jing Wang. Swarm intelligence (SI) uses food foraging behavior of animals and the concept in decentralized and selforganized system naturally[4]. SI based algorithms gives the best solution for the optimization problems 
like finding of best path for transmission, selforganization by finding of nearing neighbors. In WSN Based on the natural behavior of ant, honey bee, fish cuckoo and bat optimization problems were solved [5][6][7]. Fig.2 shows SI techniques used in

Table.1. Existing work in swarm intelligence

\begin{tabular}{|c|c|c|}
\hline Author & $\begin{array}{l}\text { Swam } \\
\text { method }\end{array}$ & Application \\
\hline $\begin{array}{l}\text { Teodorović, } \\
\text { Dušan (2008) }\end{array}$ & $\begin{array}{l}\text { Ant } \\
\text { colony }\end{array}$ & $\begin{array}{l}\text { Traffic and transportation } \\
\text { engineering applications }\end{array}$ \\
\hline $\begin{array}{l}\text { Rajani } \\
\text { Muraleedharan, } \\
\text { et.al(2008) }\end{array}$ & $\begin{array}{l}\text { Ant } \\
\text { system }\end{array}$ & Sybil attack prediction \\
\hline $\begin{array}{l}\text { Celal Ozturk } \\
\text { et.al(2011) }\end{array}$ & $\begin{array}{l}\text { Artificial } \\
\text { Bee } \\
\text { colony }\end{array}$ & $\begin{array}{l}\text { Dynamic deployment of } \\
\text { WSN }\end{array}$ \\
\hline $\begin{array}{l}\text { Buddha Singh, } \\
\text { et.al(2012) }\end{array}$ & $\begin{array}{l}\text { Particle } \\
\text { swarm } \\
\text { optimizati } \\
\text { on }\end{array}$ & $\begin{array}{l}\text { Energy-aware clusters with } \\
\text { optimal selection of cluster } \\
\text { head. }\end{array}$ \\
\hline $\begin{array}{l}\text { Gaige Wang } \\
\text { et.al(2012) }\end{array}$ & $\begin{array}{l}\text { artificial } \\
\text { bee } \\
\text { colony }\end{array}$ & $\begin{array}{l}\text { dynamic deployment } \\
\text { problem in WSN }\end{array}$ \\
\hline $\begin{array}{l}\text { Chen } \\
\text { et.al(2012) }\end{array}$ & $\begin{array}{l}\text { Hybrid } \\
\text { ABC }\end{array}$ & reduce energy depletion \\
\hline $\begin{array}{l}\text { Xiangyu Yu } \\
\text { et.al(2013) }\end{array}$ & $\begin{array}{l}\text { artificial } \\
\text { bee } \\
\text { colony }\end{array}$ & $\begin{array}{l}\text { Sensor deployment in } \\
\text { WSN }\end{array}$ \\
\hline $\begin{array}{l}\text { Thi-Kien Dao } \\
\text { et.al(2015) }\end{array}$ & $\begin{array}{l}\text { Compact } \\
\text { artificial } \\
\text { bee } \\
\text { colony }\end{array}$ & $\begin{array}{l}\text { Topology control scheme } \\
\text { in WSN }\end{array}$ \\
\hline $\begin{array}{l}\text { Yinggao Yue } \\
\text { et.al(2016) }\end{array}$ & $\begin{array}{l}\text { artificial } \\
\text { bee } \\
\text { colony }\end{array}$ & $\begin{array}{l}\text { Data collection in senor } \\
\text { network }\end{array}$ \\
\hline $\begin{array}{l}\text { Jin Wang } \\
\text { et.al }(2016)\end{array}$ & $\begin{array}{l}\text { Particle } \\
\text { swarm } \\
\text { optimizati } \\
\text { on }\end{array}$ & $\begin{array}{l}\text { Clustering with mobile } \\
\text { sink in WSN }\end{array}$ \\
\hline $\begin{array}{l}\text { Huadong } \\
\text { Wang(2016) }\end{array}$ & $\begin{array}{l}\text { artificial } \\
\text { bee } \\
\text { colony }\end{array}$ & $\begin{array}{l}\text { efficient routing protocol } \\
\text { for WSN }\end{array}$ \\
\hline $\begin{array}{l}\text { Hashim A. } \\
\text { Hashim et.al } \\
(2016)\end{array}$ & $\begin{array}{l}\text { artificial } \\
\text { bee } \\
\text { colony }\end{array}$ & $\begin{array}{l}\text { Optimal placement of relay } \\
\text { nodes in wireless sensor } \\
\text { network }\end{array}$ \\
\hline $\begin{array}{l}\text { Valero Rosset } \\
\text { et.al (2017) }\end{array}$ & $\begin{array}{l}\text { Ant } \\
\text { Colony } \\
\text { Optimizati } \\
\text { on }\end{array}$ & $\begin{array}{l}\text { Enhancing the reliability } \\
\text { on data delivery and } \\
\text { energy efficiency }\end{array}$ \\
\hline
\end{tabular}

WSN. SI models are broadly used by the researchers, in that artificial bee colony model have been used widely sensor network optimization. Table.1 shows survey on the SI algorithm used in WSN.

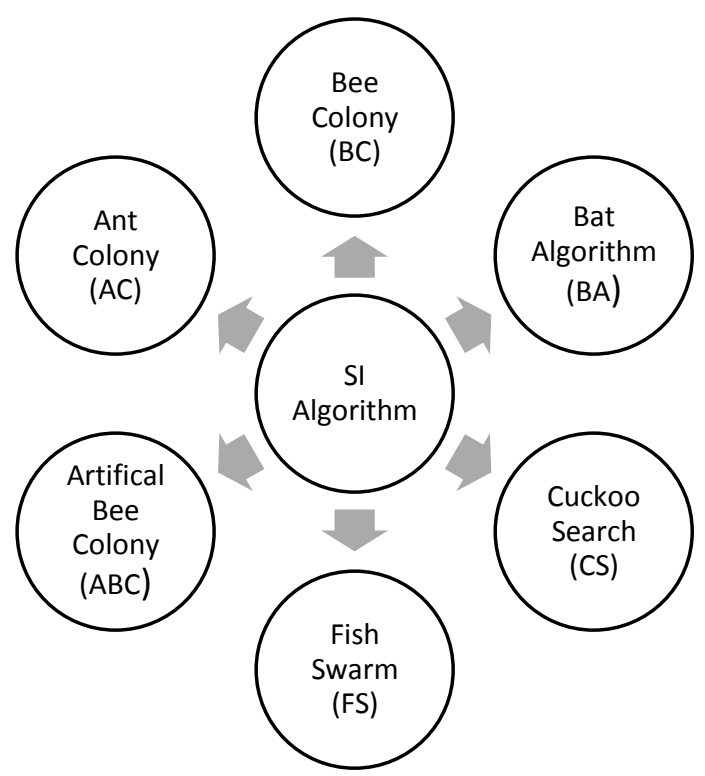

Fig.2.SI Techniques in WSN

\section{ARTIFICIAL BEE COLONY ALGORITHM:}

Artificial bee colony algorithm (ABC) is one of the SI algorithm inherits the natural honey bee food forage behavior. Bees are identifying the rich food location by conveying information among themselves which is the good example for team work, self-organizing and task performance[5].

There are three types of bee sets (employed bee, on looker bee and scout bee) being in ABC, each bee sets performs optimization process like searching of food source by employed bees, finding of the location of The $\mathrm{ABC}$ initially create a randomly distributed swarm group size denoted as $\mathrm{N}$, the $\mathrm{i}^{\text {th }}$ location of the food source is given as $A_{i}=\left\{A_{i 1}\right.$, $\left.A_{i 2}, \ldots . . . A_{i n}\right\}$, Each employed bee $A_{i}$ generates new candidate solution $\mathrm{V}_{\mathrm{i}}$ in the neighborhood of its present position $V_{i k}=A_{i k}+\varphi_{i k}\left(A_{i k}-A_{j k}\right)$. rich food source by onlooker bees and moves towards new food source by scout bees[8].

Four types of tasks performed by $\mathrm{ABC}$ algorithms[9]-,initialization, updating of population, source selection and elimination of populations.

Where, $A_{i} \neq A_{j} \quad K:\{1,2,3 \ldots \ldots n\}$ number of employed bees $\varphi_{i k}$ : Random number $[-1,+1]$

$A_{j}$ : Randomly selected food source. If the fitness value of $V_{i}$ is better than $A_{i}$, then $A_{i}$ is updated with $V_{i}$, otherwise $A_{i}$ keep unchanged. An 
onlooker bees select the food source depending upon its probability value is given as

$$
P_{i}=\frac{f i t_{i}}{\sum_{n=1}^{N} f i t_{n}}
$$

Where, fit $_{i}$ is the fitness of the $\mathrm{i}^{\text {th }}$ food source

[8] Proposed ABC based data collection algorithm, obtained prolonged network life time by improving data collection efficiency and reduce data transmission. Quantum ABC based Energy efficient cluster head selection algorithm proposed by [10], it assure reliable network connectivity and improves network efficiency. [11] Proposed ABC algorithm to solve sensor node deployment problem by made modification in scout bee phase.

\section{CONCLUSION}

It is evident, that swarm intelligence concepts has been adopted in sensor network optimization problem solving. ABC algorithm widely used in sensor network for solving problems in all aspect. It is one of the promising concept in WSN to improve network efficient in terms of node deployment, data collection, energy aware transmission and increases in network life.

\section{REFERENCE}

[1] C. Buratti, A. Conti, D. Dardari, and R. Verdone, "An overview on wireless sensor networks technology and evolution," Sensors, vol. 9, no. 9, pp. 6869-6896, 2009.

[2] I. F. Akyildiz, W. Su, Y. Sankarasubramaniam, and E. Cayirci, "Wireless sensor networks: a survey," vol. 38, pp. 393-422, 2002.

[3] R. Umashankar M L, M.V, "Optimization Techniques in Wireless Sensor Networks," Bonfring Int. J. Res. Commun. Eng., vol. 6, no.
Special Issue, pp. 83-84, 2017.

[4] D. Karaboga and B. Akay, "A survey: Algorithms simulating bee swarm intelligence," Artif. Intell. Rev., vol. 31, no. 1-4, pp. 61-85, 2009.

[5] J. A. Nandini G, "An overview of Swarm Intelligence based Algorithm for Optimization Problem in Wireless Sensor Networks," Int. J. Adv. Netw. Appl., pp. 177-181, 2016.

[6] R. V Kulkarni, S. Member, and G. Kumar, "Particle Swarm Optimization in Wireless-Sensor Networks: A Brief Survey," 262 IEEE Trans. Syst. MAN, Cybern., vol. 41, no. 2, pp. 262-267, 2011.

[7] D. Karaboga, S. Okdem, and C. Ozturk, "Cluster based wireless sensor network routing using artificial bee colony algorithm," Wirel. Networks, vol. 18, no. 7, pp. 847-860, 2012.

[8] T. Dao, T. Pan, and T. Nguyen, "A Compact Articial Bee Colony Optimization for Topology Control Scheme in Wireless Sensor Networks," J. Inf. Hiding Multimed. Signal Process., vol. 6, no. 2, pp. 297-310, 2015.

[9] Y. Yue, J. Li, H. Fan, and Q. Qin, “OptimizationBased Artificial Bee Colony Algorithm for Data Collection in Large-Scale Mobile Wireless Sensor Networks," J. Sensors, vol. 2016, no. 1, pp. 1-12, 2016.

[10] H. Wang, Y. Chen, and S. Dong, "Research on efficient-efficient routing protocol for WSNs based on improved artificial bee colony algorithm," Wirel. Sens. Syst. Res., vol. 7, pp. 1520, 2016.

[11] X. Yu, J. Zhang, J. Fan, and T. Zhang, "A faster convergence artificial bee colony algorithm in sensor deployment for wireless sensor networks," Int. J. Distrib. Sens. Networks, vol. 2013, 2013. 